\title{
JATROPHA SEED CAKE AND ORGANIC WASTE COMPOST: THE POTENTIAL FOR IMPROVEMENT OF SOIL FERTILITY
}

\author{
NAWÓZ ORGANICZNY JATROPHA ORAZ KOMPOST: \\ POTENCJAŁ ZWIĘKSZENIA ŻYZNOŚCI GLEBY
}

\begin{abstract}
Modern agriculture faces to new challenges and problems. Application of organic waste compost $\left(\mathrm{C}_{\mathrm{p}}\right)$ and Jatropha seed cake (JSC) represents new possibilities to improve soil organic matter (SOM) and thus reduce the risk of soil degradation. Our paper presents results of laboratory experiment. Based on these results, we conclude that the application of organic substances has positive effect on soil fertility but the impact of individual substances is different. JSC has higher influence on soil properties (microbial activity and plant production) in the short term. Conversely, $\mathrm{C}_{\mathrm{p}}$ affects soil properties in the long term. These properties are due to their chemical composition.
\end{abstract}

Keywords: soil fertility, Jatropha seed cake, compost, microbial activity, mineral nitrogen

\section{Introduction}

In many countries of the world soils are being degraded at an alarming rate by wind and water erosion, desertification, and salinization resulting from misuse and improper farming practices [1]. Soil health is a term which is widely used within discussions on sustainable agriculture to describe the general condition or quality of the soil resource. Soil is undeniably a very complex structure. It may be described as a multicomponent and

\footnotetext{
${ }^{1}$ Department of Geology and Pedology, Faculty of Forestry and Wood Technology, Mendel University in Brno, Zemědělská 1, 61300 Brno, Czech Republic, phone +420 545133 324, +420 545134037 , email: jakub.elbl@mendelu.cz, jindrich.kynicky@mendelu.cz

${ }^{2}$ Department of Morphology, Physiology and Animal Genetics, Faculty of Agronomy, Mendel University in Brno, Zemědělská 1, 61300 Brno, Czech Republic, phone +420 545133 146, +420 545133 155, +420 545133152 , email: petr.slama@mendelu.cz, zdenek.havlicek@mendelu.cz, eliska.kabourkova@mendelu.cz

${ }^{3}$ Department of Applied and Landscape Ecology, Faculty of Agronomy, Mendel University in Brno, Zemědělská 1, 61300 Brno, Czech Republic, phone +420 $545 \quad 132$ 484, +420 $545 \quad 132 \quad 483$, email: dana.adamcova@mendelu.cz

${ }^{4}$ Department of Agrochemistry, Soil Science, Microbiology and Plant Nutrition,_Mendel University in Brno, Zemědělská 1, 61300 Brno, Czech Republic, phone +420 $545 \quad 133$ 345, +420 $545 \quad 133 \quad 324$, email: petr.skarpa@mendelu.cz, helena.dvorackova@mendelu.cz

*Corresponding author: magda.vaverkova@uake.cz
} 
multifunctional structure with definable operating limits and a characteristic spatial configuration. Within a continuum of possibilities, there are recognizable soil types that originate depending on variations in factors, such as parent material, climate and topography, which largely determine the dominant physical and chemical properties [2]. The term soil organic matter (SOM) is generally used to represent the organic constituents in soils including un-decayed plant and animal tissues, their partial decomposition products, and the soil biomass [3]. Retain and increasing the content of SOM in agricultural land (arable soil) is essential for achieving sustainable agriculture.

Soil organisms, including micro-organisms, use soil organic matter as source of energy. Factors affecting the activity of micro-organisms in soil and their quality and quantity include content of organic substances, nitrogen compounds, macro- and micro-elements, water, and oxygen, as well as soil $\mathrm{pH}$ and temperature [4-6]. Soil organisms mobilize many main and trace nutrients (particularly $\mathrm{N}$ ) for the plant through their conversion processes alone, and are involved in particular in the nutrient cycles of carbon, nitrogen, phosphorus, and sulfur [6]. The waste products produced by micro-organisms are also soil organic matter. This waste material is less decomposable than the original plant and animal material but it can be used by a large number of organisms. By breaking down carbon structures and rebuilding new ones or storing the $\mathrm{C}$ into their own biomass, soil biota plays the most important role in nutrient cycling processes and, thus, in the ability of a soil to provide the crop with sufficient nutrients to harvest a healthy product [7]. There are many options to increase content of SOM in soil and thus reduce the risk of loss soil fertility. The most accessible method is the application of organic waste, which may be of different origin but it should be produced near the farmland where it will be applied. Application of organic waste must be carried out in accordance with relevant standards (Regulation of the European Parliament no. 1774/2002; Decree of the Czech Ministry of Agriculture no. 382/2001 Sb.; ČSN EN - Czech Technical Standard European Standard 46 5735), which specifies the procedure for the waste utilization in agriculture. This factor is very important for profitability of SOM application, especially in developing countries where farmers have limited financial resources [8-11]. Therefore, we focused on the utilization of organic waste compost $\left(\mathrm{C}_{\mathrm{p}}\right)$ and Jatropha seed cake (JSC). Industrial countries in Central Europe use the composting process primarily for disposal of municipal organic waste and organic waste from agriculture. Conversely, developing countries in South Africa do not have such resources and must search for new possibilities in agriculture. Such an opportunity is cultivation of new species of crops that have important economics and environmental properties [12].

The resulting organic waste compost contains a quality organic matter with high potential. In Central Europe, the composting process is especially used for treatment of municipal organic waste and organic waste from agriculture.

Jatropha curcas L. (JCL) is a deciduous shrub that grows up to a height of 3-5 meters and has productive life of 50 years. It belongs to the family of Euporbiaceae. JCL is believed to have been spread by Portuguese seafarers from its center of origin in Central America and Mexico via Cape Verde and Guinea Bissau to other countries in Africa and Asia. It is now widespread throughout the tropics and sub-tropics. The possibility of growing JCL for the purpose of producing biofuel is really attractive and gets attention of investors and policy-makers worldwide. The seeds of JCL contain non-edible oil with properties that are well suited for the production of biodiesel. Although optimum ecological conditions for JCL production are in the warm subhumid tropics and subtropics, JCL's 
ability to grow in dry areas on degraded soils, that are marginally suited for agriculture, makes it especially attractive. In addition, JCL can be used as a living fence to keep out livestock, control soil erosion and improve water infiltration. The waste products from JCL biodiesel production, JSC, can be used as fertilizer or livestock feed and for producing biogas [13].

This study evaluates the potential of using $\mathrm{C}_{\mathrm{p}}$ and JSC as a source of organic nutrient to further nurture the growth of crops. More than a decade ago, it had been reported that there was a usage of JSC as fertilizer for growing potatoes [14]. There were shown that crops of pearl millet, cabbage, and rice had high percent of yield increases after an application of JSC as fertilizer comparing to none application [15].

The aims of the present study were therefore as follows: (1) to investigate the influence of $\mathrm{C}_{\mathrm{p}}$ and JSC application on soil fertility (2) to investigate the different impact of JSC on soil fertility in comparison with $\mathrm{C}_{\mathrm{p}}(3)$ the possibility of using of organically treated waste $\left(\mathrm{C}_{\mathrm{p}}\right.$ and $\mathrm{JSC}$ ) to improve soil fertility and thus soil resiliency to negative phenomena.

\section{Materials and methods}

\section{Design of experiment}

Presented hypotheses were tested by pot experiment which was carried out in a grow box. The experiment was conducted in the period from 1st February to 20th March 2014 (48 days). During the whole experiment, plants were kept in a climate chamber at $22.5^{\circ} \mathrm{C}$ with a day length of 12 hours and light intensity of $350 \mu \mathrm{mol} / \mathrm{m} \cdot \mathrm{s}$. Twenty-one experimental pots of a diameter $115 \mathrm{~mm}$ and height $110 \mathrm{~mm}$ were prepared. Lettuce (Lactuca sativa) was used as an indicator plant to determine the influence of $\mathrm{C}_{\mathrm{p}}$ and JSC application on plant production. Each experimental pot was filed with $1100 \mathrm{~g}$ of arable soil with or without addition of $\mathrm{C}_{\mathrm{p}}$, JSC or with mixed $\mathrm{C}_{\mathrm{p}}$ and JSC. Soil sampling was carried out on $25^{\text {th }}$ November 2013 in accordance with the Czech National Standard ČSN ISO 10 381-6. $\mathrm{C}_{\mathrm{p}}$ was obtained from the Central Composting Plant in Brno which is registered for agriculture use in the Czech Republic. Information about the chemical composition of used $C_{p}$ are listed in Table 1. Used $C_{p}$ was prepared by outdoor composting process in piles with mechanical aeration. The $\mathrm{C}_{\mathrm{p}}$ used corresponded to three-month-old mature compost, which was provided by a full-scale aerobic composting plant located in Brno - Černovice (Czech Republic). Samples of $C_{p}$ were taken on $27^{\text {th }}$ November 2013 in accordance with the Czech National Standard CSN EN 46 5735. Soil and $\mathrm{C}_{\mathrm{p}}$ samples used for the experiment were sieved through a sieve (grid size of $2 \mathrm{~mm}$ ). Before storage, the samples of soil were pre-incubated at $18.5^{\circ} \mathrm{C}$ in laboratory for 30 days. Prepared samples of $\mathrm{C}_{\mathrm{p}}$ and soil were stored in a thermostat at a temperature of $3.5^{\circ} \mathrm{C}$. JSC was purchased from Zambian farmer on 18th November 2012 and transported to the Czech Republic on $22^{\text {th }}$ November. Before storage, this material was sieved through a sieve (grid size of $2 \mathrm{~mm}$ ) and then stored in thermostat at $3.5^{\circ} \mathrm{C}$.

To demonstrate effect of $\mathrm{C}_{\mathrm{p}}$ and JSC application, seven variants of experiment (identified as V1-V7 on Figures) with different doses of these fertilizers were prepared (Fig. 1). Each one was prepared in three repetitions. Individual doses were recalculated according to the dry matter content (density of used arable soil $=1571 \mathrm{~kg} / \mathrm{m}^{3}$ ):

- V1: variant without addition of fertilizers - $1100 \mathrm{~g}$ of arable soil (identified as control in text; 180).

- $\quad$ V2: dose of $23.4 \mathrm{~g}$ of JSC (representing $50 \mathrm{Mg} / \mathrm{ha}$ ) identified as $\mathrm{S}+\mathrm{J} 50 \mathrm{Mg}$ 
- V3: dose of $46.8 \mathrm{~g}$ of JSC (representing $100 \mathrm{Mg} / \mathrm{ha}$ ) identified as S+J $100 \mathrm{Mg}$

- V4: dose of $33.2 \mathrm{~g}$ of $\mathrm{C}_{\mathrm{p}}$ (representing $50 \mathrm{Mg} / \mathrm{ha}$ ) identified as $\mathrm{S}+\mathrm{C}_{\mathrm{p}} 50 \mathrm{Mg}$

- V5: dose of $66.4 \mathrm{~g}$ of $\mathrm{C}_{\mathrm{p}}$ (representing $100 \mathrm{Mg} / \mathrm{ha}$ ) identified as $\mathrm{S}+\mathrm{C}_{\mathrm{p}} 100 \mathrm{Mg}$

- V6: combined dose of $16.6 \mathrm{~g}$ of $\mathrm{C}_{\mathrm{p}}$ and $11.7 \mathrm{~g}$ of JSC (this combined dose representing $25 \mathrm{Mg} / \mathrm{ha}$ of $\mathrm{C}_{\mathrm{p}}$ and $25 \mathrm{Mg} / \mathrm{ha}$ of JSC) identified as $\mathrm{S}+\mathrm{C}_{\mathrm{p}}+\mathrm{J} 25 \mathrm{Mg}$

- V7: combined dose of $33.2 \mathrm{~g}$ of $\mathrm{C}_{\mathrm{p}}$ and 23,4 $\mathrm{g}$ of JSC (this combined dose representing $50 \mathrm{Mg} / \mathrm{ha}$ of $\mathrm{C}_{\mathrm{p}}$ and $50 \mathrm{Mg} / \mathrm{ha}$ of JSC) identified as $\mathrm{S}+\mathrm{C}_{\mathrm{p}}+\mathrm{J} 50 \mathrm{Mg}$

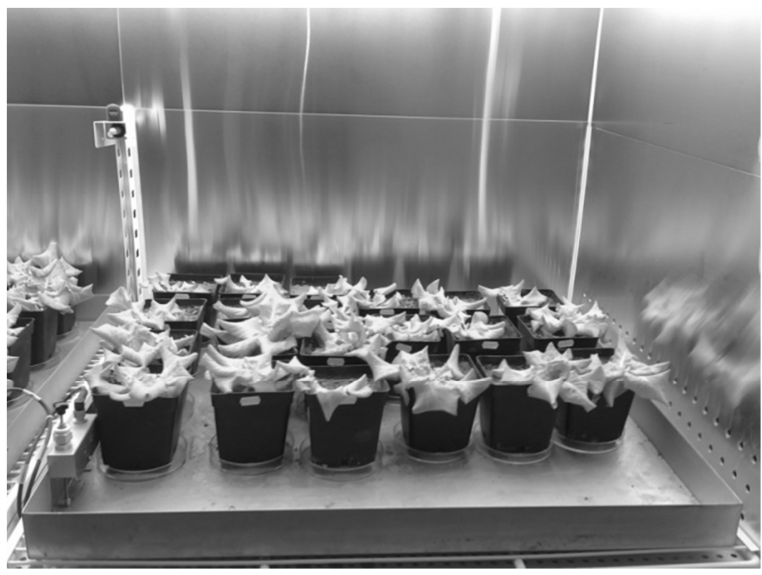

Fig. 1. Location of experimental containers in a growth box

\section{Analysis of the arable soil and fertilizers chemical properties (organic substances)}

The basic properties (available nutrients, soil reaction, $\mathrm{C}_{\text {tot }}$ and $\mathrm{N}_{\mathrm{tot}}$ ) were determined in homogenized sample of arable soil, $\mathrm{C}_{\mathrm{p}}$ and JSC. Available nutrients: $\mathrm{P}, \mathrm{K}, \mathrm{Ca}$ and $\mathrm{Mg}$ were extracted by Mehlich III according to Mehlich [16]. Subsequently the content of these nutrients in the extract was measured by Manasek et al [17]: available phosphorus (P) in the extract was determined colorimetrically and the content of available potassium (K), magnesium $(\mathrm{Mg})$ and calcium (Ca) by atomic absorption spectrometry (AAS). The ion-selective electrode (ISE) method was used to determine the $\mathrm{pH}$ value after extraction in $0.01 \mathrm{M} \mathrm{CaCl}_{2} . \mathrm{C}_{\text {tot }}$ and $\mathrm{N}_{\text {tot }}$ were measured according to Nelson and Sommers [18] and Bremmer [19].

\section{Determination of substrate induced respiration}

Substrate induced respiration (SIR) was determined by measuring the $\mathrm{CO}_{2}$ production from soils incubated in serum bottles for 4 hours after the addition of glucose. Field-moist soil $(5 \mathrm{~g})$ was added to three replicate serum bottles and $2 \mathrm{~cm}^{3}$ of a glucose solution was added to each bottle ( $4 \mathrm{mg} \mathrm{C/g}$ of dry soil). Bottles were sealed with butyl rubber stoppers, and soils were incubated at $25^{\circ} \mathrm{C}$. After 2 and 4 hours, a $0.5 \mathrm{~cm}^{3}$ sample of the internal atmosphere was analyzed by gas chromatography (see previous section). SIR was calculated from the $\mathrm{CO}_{2}$ increase during the $4 \mathrm{~h}$ incubation period according Simek et al [20]. 


\section{Measurement of the leaching of mineral nitrogen}

The leaching of $\mathrm{N}_{\min }$ was measured according Elbl et al [10]: $\mathrm{N}_{\min }$ (consisting of ammonium nitrogen $\mathrm{NH}_{4}{ }^{+} \mathrm{N}$ and nitrate nitrogen $\mathrm{NO}_{3}{ }^{-} \mathrm{N}$ ), which leached out of the experimental containers, was captured by resin grain. These grains were placed into special plastic (PVC) discs that were located under all containers. Each disc was composed of a plastic ring that was $75 \mathrm{~mm}$ wide and $5 \mathrm{~mm}$ thick. From both side of each disc, nylon mesh (special type UHELON) was glued (grid size of $0.1 \mathrm{~mm}$ ). Resin grains for capture of $\mathrm{N}_{\min }$ are called ion exchange resin (IER). Mixed IER was used for this experiment. This IER consists of cation exchange resin (CER for capturing $\mathrm{NH}_{4}{ }^{+}-\mathrm{N}$ ) and anion exchange resin (AER - for capturing $\mathrm{NO}_{3}{ }^{-} \mathrm{N}$ ) in ratio 1:1. IER used for experiment were made by Purolite Company (France). These types were applied: (1) AER Macroporous Strong Base Anion Exchange Resin - A520E (total capacity $0.9 \mathrm{eq} / \mathrm{dm}^{3}$ ) and (2) CER Gel Strong Acid Cation Resin - C100E (total capacity $1.9 \mathrm{eq} / \mathrm{dm}^{3}$ ).

Trapped ions of ammonium- $\mathrm{N}$ and nitrate- $\mathrm{N}$ were quantified according Novosadova et al [21]: the IER were dried at room temperature. Absorbed $\mathrm{NH}_{4}{ }^{+}-\mathrm{N}$ and $\mathrm{NO}_{3}{ }^{-} \mathrm{N}$ were evaluated from IER using $100 \mathrm{~cm}^{3} 1.7 \mathrm{M} \mathrm{NaCl}$ and determined by distillation and titration method according Peoples et al [22]. The results obtained from the discs with IER were expressed in $\mathrm{mg}$ of $\mathrm{N}_{\min }\left(\mathrm{NH}_{4}{ }^{+}-\mathrm{N} / \mathrm{NO}_{3}{ }^{-} \mathrm{N}\right)$ per $\mathrm{m}^{2}$ of soil surface/surface of experimental containers $\left[\mathrm{mg} / \mathrm{m}^{2}\right]$.

\section{Results and discussion}

\section{Properties of compost, Jatropha seed cake and soil}

Brittaine and Lutaladio [13] state that Jatropha curcas L. can be used for production of wood, oil, green manure and for erosion control and to improve water infiltration. Especially production of oil from the seeds is very interesting for farmers in developing countries because of its high economical profit. After the production process, farmers receive high-quality fertilizer in the form of "biological-waste" that is generated by pressing the seeds. This "biological-waste" is known as the JSC and it represents an excellent organic matter with high nitrogen content.

Table 1

Arable soil and fertilizers chemical properties supplemented with trace elements

\begin{tabular}{|c|c|c|c|c|c|c|c|c|}
\hline \multirow{3}{*}{ Sample } & \multicolumn{8}{|c|}{ Methods } \\
\hline & \multicolumn{5}{|c|}{$\begin{array}{l}\text { Mehlich [16] and Manasek et al [17]; } \\
\text { available nutrients content }\end{array}$} & \multirow{2}{*}{$\begin{array}{c}\begin{array}{c}\text { Nelson and } \\
\text { Sommers [18] }\end{array} \\
\begin{array}{c}\mathrm{C}_{\text {tot }} \\
{\left[\mathrm{g}^{\circ} \mathrm{kg}^{-1}\right]}\end{array} \\
\end{array}$} & \multirow{2}{*}{$\begin{array}{c}\begin{array}{c}\text { Bremmer } \\
{[19]}\end{array} \\
\begin{array}{c}\mathbf{N}_{\text {tot }} \\
{\left[\mathrm{g} \cdot \mathbf{k g}^{-1}\right]}\end{array}\end{array}$} & \multirow[b]{2}{*}{$\mathrm{C} / \mathrm{N}$} \\
\hline & $\begin{array}{c}\mathbf{p H} \\
\left(\mathrm{CaCl}_{2}\right)\end{array}$ & $\begin{array}{c}\mathbf{P} \\
{\left[\mathrm{mg} \cdot \mathrm{kg}^{-1}\right]}\end{array}$ & $\begin{array}{c}\mathrm{K} \\
{\left[\mathrm{mg} \cdot \mathbf{k g}^{-1}\right]}\end{array}$ & $\begin{array}{c}\mathrm{Ca} \\
{\left[\mathrm{mg} \cdot \mathbf{k g}^{-1}\right]}\end{array}$ & $\begin{array}{c}\mathrm{Mg} \\
{\left[\mathrm{mg}^{\left.-\mathrm{kg}^{-1}\right]}\right.}\end{array}$ & & & \\
\hline $\begin{array}{c}\text { Arable } \\
\text { soil }\end{array}$ & 6.32 & 180.61 & 167.80 & 1449.00 & 52.50 & 13 & 1.41 & 9.19 \\
\hline $\mathrm{C}_{\mathrm{p}}$ & 8.06 & 565.23 & 6422.00 & 11235.00 & 1255.00 & 166.53 & 1593 & 10.45 \\
\hline JSC & 6.81 & 353.73 & 9818.00 & 829.00 & 3301.00 & 464.27 & 20.87 & 22.25 \\
\hline
\end{tabular}

The Table 1 shows the complete overview of arable soil, $\mathrm{C}_{\mathrm{p}}$ and JSC properties. The above information indicates that there can be differences between $\mathrm{C}_{\mathrm{p}}$ and JSC in effects on soil properties. JSC is a fertilizer with high nitrogen and carbon content than $\mathrm{C}_{\mathrm{p}}$. Moreover, Selanon et al [24] reported that JSC containing high protein has served as a source of protein hydrolysate applied for plant growth stimulation. In addition, soil reaction $(\mathrm{pH})$ and 
content of essential nutrients $(\mathrm{P}, \mathrm{K}, \mathrm{Ca}$ and $\mathrm{Mg})$ are very important indicators which directly affect the soil microbial activities and subsequently soil fertility. Data in Table 1 show differences in content of plant available nutrients and soil reaction between $\mathrm{C}_{\mathrm{p}}$ (higher content of $\mathrm{P}$ and $\mathrm{Ca}$ ) and JSC (lower soil reaction; higher content of $\mathrm{K}$ and $\mathrm{Mg}$ ). Based on these data, authors conclude that properties of $\mathrm{C}_{\mathrm{p}}$ and JSC directly affected the main objectives of experiment.

\section{Effect of organic material addition on substrate induced respiration - on potential microbial activity in soil}

The soil respiration is an important indicator the soil state. The substrate-induced respiration (SIR) consists in the measurement of microbial respiration of samples after amending them with an excess of a readily nutrient source, usually glucose, to trigger microbial activity. Thus, the initial maximum respiratory response, which has to be optimized for every new kind of sample, is related with the current size of living microbial biomass $[25,26]$. SIR serves as a means of quantifying microbial activities in soils. Results of substrate induced respiration are shown in Figure 2. The results of SIR were expressed in microgram of carbon dioxide per gram of soil and one hour.

The Figure 2 shows significant differences in production of $\mathrm{CO}_{2}$ between variants with and without addition of JSC. The significant (ANOVA; $\mathrm{P}<0.05$ ) highest microbial activity was measured in variants with application of JSC ( $\mathrm{S}+\mathrm{J} 50 \mathrm{Mg}$ ) and a mixture of JSC and $\mathrm{C}_{\mathrm{p}}$ $\left(\mathrm{S}+\mathrm{C}_{\mathrm{p}}+\mathrm{J} 25 \mathrm{Mg}\right)$ in comparison with control variant and variant where $\mathrm{C}_{\mathrm{p}}$ was applied. This is due to the fact that JSC contains high amounts of simple sugars supporting microbial activity.

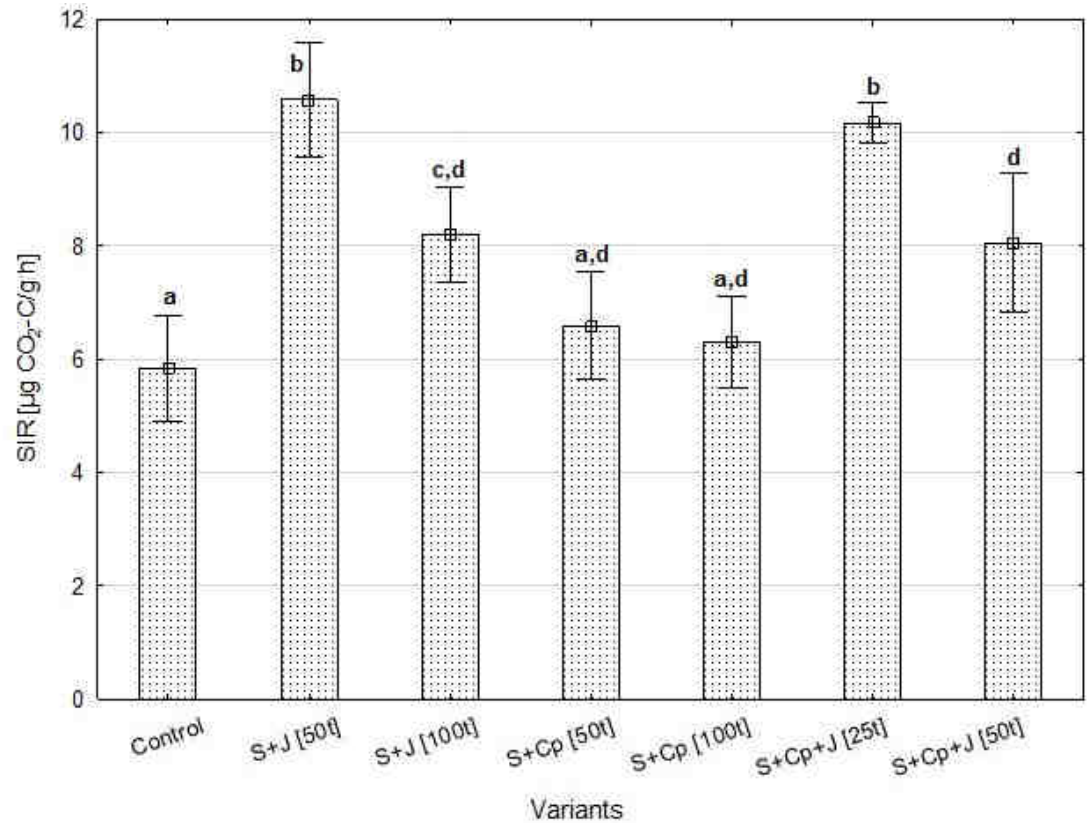

Fig. 2. Substrate induced respiration (mean values \pm standard error, $n=3$, different letters indicate a significant differences in SIR at the level 0.05 - ANOVA, $p<0.05$ ) 
Bloem and Hopkins [27] state: Soil respiration is a key process for carbon flux to the atmosphere. Soil water content, oxygen concentration and the bioavailability of carbon are the main factors that regulate soil respiration. Consider data which are presented in the Table 1. These data show differences in chemical composition between $\mathrm{C}_{\mathrm{p}}$ and JSC. According Brittaine and Lutaladio [13] JSC contains organic and nitrogen compounds which are easily degradable by soil organisms. Therefore, the JSC is useful as a source of energy for soil microorganisms. The application of JSC contributes to the development of microbial activity and subsequently to an increase in production of carbon dioxide and utilization of glucose/carbon compounds.

Positive effect of JSC addition on microbial activity in soil was confirmed by Brittaine and Lutaladio [13]. Moreover, Wolf and Snyder [8]; Donn et al [23] and Ouni et al [28] state that the applications of organic substances are fundamental to improve soil fertility. The size of the applied dose of organic materials ( $C_{p}$ and JSC) must be determined on the basis of their composition and saturation of the soil sorption complex. The authors draws particular attention to the possibility of increasing the content of organic compounds (eutrophication), salts and heavy metals in the soil. Disposable high doses of $\mathrm{C}_{\mathrm{p}}$ or JSC in can lead to formation of toxicity of arable land for soil microbes. Compare the amount of SIR in variant $\mathrm{S}+\mathrm{J}(50 \mathrm{Mg})$ with measured value of SIR in $\mathrm{S}+\mathrm{J}(100 \mathrm{Mg})$. These data indicate that the dose $50 \mathrm{Mg} / \mathrm{ha}$ was more optimal than $100 \mathrm{Mg} / \mathrm{ha}$. Moreover the same decrease in value of SIR is between variants $\mathrm{S}+\mathrm{C}_{\mathrm{p}}+\mathrm{J}(25 \mathrm{Mg})$ and $\mathrm{S}+\mathrm{C}_{\mathrm{p}}+\mathrm{J}(50 \mathrm{Mg})$. Based on these values, we conclude that increased dose of JSC (50 Mg) had a negative effect on microbial communities and this effect is caused by JSC composition (see Table 2; the deoiled seed cake was used). The potential risk of high doses of JSC application on soil health and quality was studied and reported by Brittaine and Lutaladio [13], Hidayat et al [30] and Srinophakun et al [31].

Table 2

Composition of de-oiled JCL samples [wt.\% on dry basis], Hidayat et al [30]

\begin{tabular}{|c|c|c|c|}
\hline \multicolumn{2}{|c|}{ Component } & $\begin{array}{c}\text { Deoiled seed shell } \\
\text { (DSS) }\end{array}$ & $\begin{array}{c}\text { Deoiled seed cake } \\
\text { (DSC) }\end{array}$ \\
\hline \multirow{4}{*}{\begin{tabular}{c} 
Total saccharides [\%] \\
DSS $=44.21$ \\
\cline { 2 - 4 }
\end{tabular}} & Arabinose & 0.66 & 1.27 \\
\cline { 2 - 4 } & Xylose & 12.11 & 7.34 \\
\cline { 2 - 4 } & Mannose & 1.30 & 0.96 \\
\cline { 2 - 4 } & Galactose & 0.97 & 1.01 \\
\cline { 2 - 4 } & Glucose & 28.85 & 0.23 \\
\hline \multirow{2}{*}{$\begin{array}{c}\text { Total lignin }[\%] \\
\text { DSS }=44.04 \\
\text { DSC }=28.84\end{array}$} & $\begin{array}{c}\text { Acid insoluble } \\
\text { lignin }\end{array}$ & 0.31 & 28.25 \\
\cline { 2 - 4 } & $\begin{array}{c}\text { Acid soluble } \\
\text { lignin }\end{array}$ & 43.71 & 0.59 \\
\hline
\end{tabular}

\section{Effect of organic fertilizers addition on mineral nitrogen loss from arable soil}

Leaching of mineral nitrogen $\left(\mathrm{N}_{\text {min }}\right)$ from arable soil is a major threat to the drinking water quality of underground reservoirs in the Czech Republic [10]. The Figure 3 presents results of leaching of mineral nitrogen from experimental containers. The greatest loss of $\mathrm{N}_{\min }$ was detected in variants with application of JSC (S+J $100 \mathrm{Mg} ; \mathrm{S}+\mathrm{J} 50 \mathrm{Mg}$ ) and a mixture of JSC and $\mathrm{C}_{\mathrm{p}}\left(\mathrm{S}+\mathrm{C}_{\mathrm{p}}+\mathrm{J} 50 \mathrm{Mg}\right)$. In addition, dose $50 \mathrm{Mg}$ of JSC per ha contains $1043 \mathrm{~kg}$ of $\mathrm{N}_{\text {tot }}$ and dose $50 \mathrm{Mg}$ of $\mathrm{C}_{\mathrm{p}}$ per ha $796.5 \mathrm{~kg}$ of $\mathrm{N}_{\text {tot }}$. This difference is significant 
in comparison with control variant and variant where $\mathrm{C}_{\mathrm{p}}$ was applied. JSC contains a large number of simple carbon compounds and nitrogen compounds; they can be easily used by plants and soil microorganisms. But if the soil is not ready for it, a loss of nutrients occurs $\left(\mathrm{N}_{\text {min }}\right)$ through leaching. In contrast, if the compost is stabilized, so that nutrients will be released slowly. Plant and soil microorganisms receive them slowly. Therefore, significant lowest loss of $\mathrm{N}_{\min }$ was found in variant $\mathrm{S}+\mathrm{C}_{\mathrm{p}}(50 \mathrm{Mg})$ in comparison with $\mathrm{S}+\mathrm{J}(50 \mathrm{Mg})$ and $\mathrm{S}+\mathrm{C}_{\mathrm{p}}+\mathrm{J}(25 \mathrm{Mg})$.

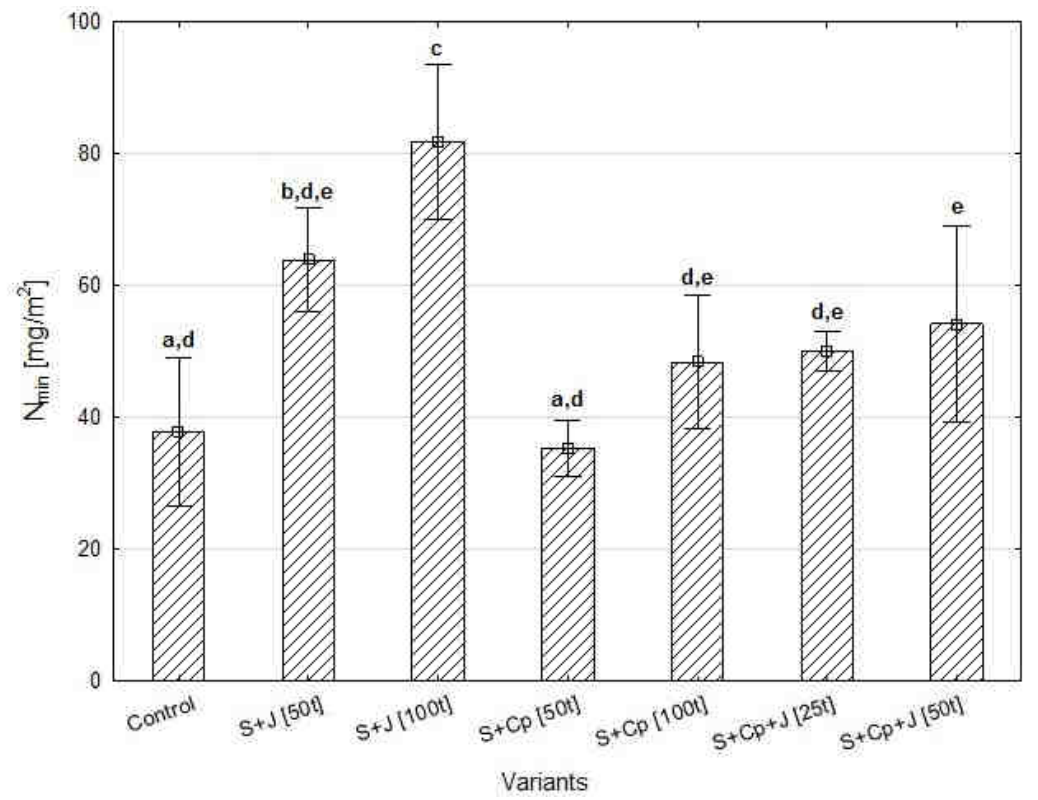

Fig. 3. Loss of mineral nitrogen from experimental containers (mean values \pm standard error, $n=3$, different letters indicate a significant differences in SIR at the level 0.05 - ANOVA, $p<0.05$ )

Influence of type of fertilization and kind of fertilizers on loss of $\mathrm{N}_{\min }$ from arable soil was studied and confirmed by Wolf and Snyder [8]; Simek et al [20] and Donn et al [23]. Conversely positive effect of $\mathrm{C}_{\mathrm{p}}$ application on the content and store of nitrogen in arable soil was published in Diaz et al [9]; Nevens and Reheul [11] and Mylavarapu and Zinati [29]. The positive effect of the $C_{p}$ addition on leaching of $N_{\min }$ is based on its chemical composition. The chemical compounds of $\mathrm{C}_{\mathrm{p}}$ are interesting. Among the most important substances in $\mathrm{C}_{\mathrm{p}}$ : carbon, two forms of nitrogen (organic and inorganic) and phosphorus are available. More than $85-90 \%$ of the total nitrogen content in $\mathrm{C}_{\mathrm{p}}$ is organic, while the remaining $10-15 \%$ is inorganic and immediately available to the plants. Moreover, available carbon (from $\mathrm{C}_{\mathrm{p}}$ ) is source of energy for microorganisms, thus this energy can be subsequently used for the processing of nitrogen. Increasing microbial activity results in increased capacity for $\mathrm{N}_{\text {min }}$ retention (additionally supplied from compost and another mineral fertilizer). $\mathrm{N}_{\min }$ is captured in $\operatorname{SOM}[9,10]$. 


\section{Effect of organic material's addition on plant production}

Production of lettuce (Lactuca sativa) was chosen as the main indicator of the influence of the above organic substrates application. Results of production of plant biomass are shown in Figure 4. The significant greatest production of plant biomass was found in the variant with application of JSC (S+J $50 \mathrm{Mg}$ ). This is due to the JSC's content of large number of available carbon and nitrogen compounds while production of plant biomass in the variant with application a mixture of $\mathrm{C}_{\mathrm{p}}$ and $\mathrm{JSC}\left(\mathrm{S}+\mathrm{C}_{\mathrm{p}}+\mathrm{J} 25 \mathrm{Mg}\right)$ was only slightly higher than in control variant.

Brittaine and Lutaladio [13] state that JSC contains a large number of nutrients in different forms which are useful as a source of nutrients for soil microorganisms and subsequently also for plants. Consider production of plant biomass in variants $\mathrm{S}+\mathrm{J}(50 \mathrm{Mg})$ and $\mathrm{S}+\mathrm{C}_{\mathrm{p}}(50 \mathrm{Mg})$ with loss of $\mathrm{N}_{\min }$. These values indicate that the application of organic matter contributes to the development of microbial activity and thus to the development of soil organic - mineral complex, which is essential for uptake and utilization of nutrient in soil and for plant production.

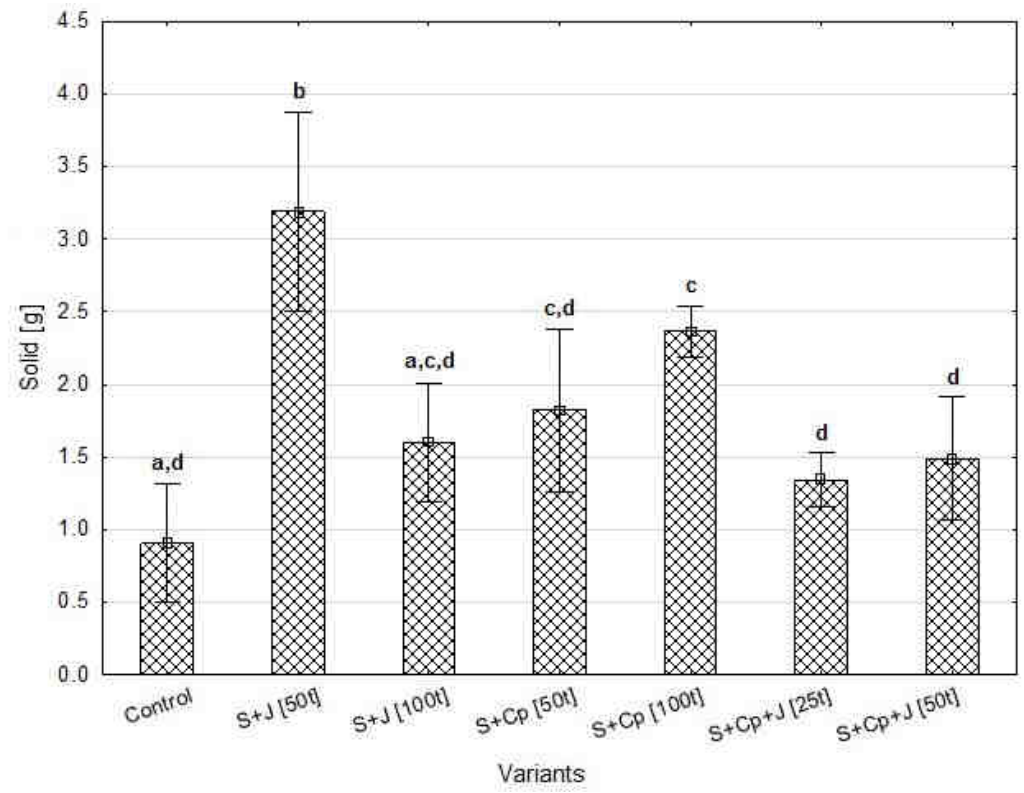

Fig. 4. Production of plant biomass (mean values \pm standard error, $n=3$, different letters indicate a significant differences in production of plant biomass at the level 0.05 - ANOVA, $p<0.05$ )

\section{Conclusion}

Modern agriculture faces to new challenges and problems. One of the greatest threats is depletion in soil fertility. Therefore, we must search for news biotechnology to maintain soil fertility and renewal of its natural properties. Application of $\mathrm{C}_{\mathrm{p}}$ and JSC represents new possibilities to improve SOM and thus reduce the risk of soil degradation. Our paper presents results of laboratory experiment. Based on these results, we conclude that the application of above organic substances has positive effect on soil fertility but the impact of 
individual substances is different. JSC has higher influence on soil properties (microbial activity and plant production) in the short term. Conversely, $\mathrm{C}_{\mathrm{p}}$ affects soil properties in the long term. These properties are due to their chemical composition.

\section{Acknowledgements}

This study was supported by the IGA - Internal Grant Agency Faculty of Agronomy MENDELU No. TP 3/2015.

\section{References}

[1] Papendick RI, Parr JF. Soil quality - The key to a sustainable agriculture. Am J Alter Agric. 1992;7(1-2):2-3. DOI: 10.1017/S0889189300004343. http://www.journals.cambridge.org/ abstract_S0889189300004343.

[2] Kibblewhite MG, Ritz K, Swift MJ. Soil health in agricultural systems. Philosoph Transact B. 2008;363(1492):685-701. DOI: 10.1098/rstb.2007.2178. http://rstb.royalsocietypublishing.org/cgi/doi/ 10.1098/rstb.2007.2178.

[3] Zbytniewski R, Buszewski B. Sorption of pesticides in soil and compost. Pol J Environ Stud. 2002;11(2):179-184. http://www.pjoes.com/index.php?s=abs_id\&id=2002110211.

[4] Wolińska A, Stępniewska Z, Szafranek-Nakonieczna A. Effect of selected physical parameters on respiration activities in common Polish mineral soil. Pol J Environ Stud. 2011;20(4):1075-1082. http://www.pjoes.com/index.php?s=abs_id\&id=2011200433.

[5] Martyn W, Skwaryło-Bednarz B. Biological properties of light soils in the area of Roztocze National Park. Acta Agrophys. 2005;5(3):695-704. http://www.old.acta-agrophysica.org/en/semi_year_book.html? stan $=$ detail\&paper $=508 \& \mathrm{i}=21 \& \mathrm{vol}=5 \&$ numer $=3$.

[6] Klikocka H, Narolski B, Klikocka O, Głowacka A, Juszczak D, Onuch J, et al. The effect of soil tillage and nitrogen fertilization on microbiological parameters of soil on which spring triticale is grown. Pol J Environ Stud. 2012;21(6):1675-1685. http://www.pjoes.com/index.php?s=abs_id\&id=2012210620.

[7] Bot A, Benites J. The importance of soil organic matter: key to drought-resistant soil and sustained food production. Rome: Food and Agriculture Organization of United Nations; 2005. www.fao.org/3/a-a0100e.pdf.

[8] Wolf B, Snyder H. Sustainable Soils: The Place of Organic Matter in Sustaining Soils and Their Productivity. New York: Food Products Press; 2003.

[9] Diaz LF, Bertoldi DM, Bidlingmaier W. Compost Science and Technology. Boston: Elsevier; 2007.

[10] Elbl J, Plošek, Kintl A, Přichystalová J, Záhora J, Friedel JK. The effect of increased doses of compost on leaching of mineral nitrogen from arable land. Pol J Environ Stud. 2014;23(3):697-703. http://www.pjoes.com/pdf/23.3/Pol.J.Environ.Stud.Vol.23.No.3.697-703.pdf.

[11] Nevens F, Reheul D. The application of vegetable, fruit and garden waste (VFG) compost in addition to cattle slurry in a silage maize monoculture: nitrogen availability and use. Eur J Agron 2003;19(2):189-203. DOI: 10.1016/S1161-0301(02)00036-9. http://linkinghub.elsevier.com/retrieve/pii/S1161030102000369.

[12] Elbl J, Foltýnová A, Stroblová M, Plošek L, Kintl A. The combined effects of application of biological waste from processing of Jatropha curcas L. and organic waste compost on arbuscular mycorrhiza and on loss of ammonium nitrogen from rhizosphere soil. Acta Facultatis Ecologiae. 2014;31:5-13. http://www.tuzvo.sk/sk/organizacna_struktura/fakulta_ekologie_a_environmentalistiky/veda_a_vyskum/act a_facultatis_ecologiae/acta_facultatis_ecologiae_eng.html.

[13] Brittaine R, Lutaladio N. Jatropha: a smallholder bioenergy crop: the potential for pro-poor development. Rome: Food and Agriculture Organization of the United Nations; 2010. www.fao.org/docrep/012/i1219e/i1219e.pdf.

[14] Gubitz GM, Mittelbach M, Trabi M. Exploitation of the tropical oil seed plant Jatropha curcas L. Biores Technol. 1999;67(1):73-82. DOI: 10.1016/S0960-8524(99)00069-3. http://linkinghub.elsevier.com/ retrieve/pii/S0960852499000693.

[15] Achten WMJ, Verchot L, Frankenc YJ, Mathijsd E, Singhe VP, Aertsa R, et al. Jatropha bio-diesel production and use. Biomass Bioenerg. 2008;32:1063-1084. DOI: 10.1016/j.biombioe.2008.03.003. http://linkinghub.elsevier.com/retrieve/pii/S0961953408000767.

[16] Mehlich A. Mehlich 3 soil test extractant: A modification of Mehlich 2 extractant. Commun Soil Sci Plant Analysis. 1984;15(12):1409-1416. DOI: 10.1080/00103628409367568. http://www.tandfonline.com/doi/ abs/10.1080/00103628409367568. 
[17] Maňásek J, Lošák T, Prokeš K, Hlušek J, Vítězová M, Škarpa P, et al. Effect of nitrogen and Potassium fertilization on micronutrient content in grain maize (Zea mays L.). Acta Universitatis Agriculturae et Silviculturae Mendelianae Brunensis. 2013;61(1):123-128. http://acta.mendelu.cz/61/1/0123/.

[18] Nelson DW, Sommers LE. Total carbon, organic carbon, and organic matter. In: Sparks DL, editor. Methods of Soil Analysis. Part 3, Book Series No. 5. Madison, Wisconsin: Soil Science Society of America; 1996.

[19] Bremner JM. Nitrogen total. In: Sparks DL, editor. Methods of Soil Analysis, Part 3: Chemical Methods. Book Series No. 5. Madison, Wisconsin: Soil Science Society of America; 1996.

[20] Šimek M, Virtanen S, Krištůfek V, Simojoki A, Yli-Halla M. Agric Eco Environ. 2011;140(1-2)113-122. DOI:10.1016/j.agee.2010.11.018. http://linkinghub.elsevier.com/retrieve/pii/S0167880910003099.

[21] Novosadová I, Záhora, J, Sinoga RD. The availability of mineral nitrogen in mediterranean open steppe dominated by Stipa tenacissima L. Acta Universitatis Agriculturae et Silviculturae Mendelianae Brunensis 2011;59(5)187-192. http://acta.mendelu.cz/59/1/0183/.

[22] Peoples MB, Faizah AW, Perkasem B, Herridge DD. Methods for Evaluating Nitrogen Fixation by Modulated Legumes in the Field. Canberra: Australian Centre for International Agricultural Research; 1989.

[23] Donn S, Wheatley RE, Mckenzie BM, Loades KW, Hallett PD. Improved soil fertility from compost amendment increases root growth and reinforcement of surface soil on slopes. Ecol Eng. 2014;71:458-465. DOI: 10.1016/j.ecoleng.2014.07.066. http://www.sciencedirect.com/science/article/pii/ S0925857414003577.

[24] Selanon O, Saetae D, Suntornsuk W. Biocatal Agric Biotechnol. 2014;3(4):114-120. DOI: 10.1016/j.bcab.2014.08.001. http://www.sciencedirect.com/science/article/pii/S1878818114001078.

[25] Aira M, Domínguez J. Substrate-induced respiration as a measure of microbial biomass in vermicomposting studies. Biores Technol. 2010;101(18):7173-7176. DOI: 10.1016/j.biortech.2010.03.137. http://www.ncbi.nlm.nih.gov/pubmed/20400302.

[26] Aderson JPE, Domsch KH.. A physiological method for the quantitative measurement of microbial biomass in soils. Soil Biol Biochem. 1978;10(3):215-221. DOI: 10.1016/0038-0717(78)90099-8. http://linkinghub.elsevier.com/retrieve/pii/0038071778900998.

[27] Bloem J, Hopkins DW. Microbiological Methods for Assessing Soil Quality. Cambridge: CABI Publishing; 2006.

[28] Ouni Y, Lakhdar A, Scelza R, Scotti R, Abdelly Ch, Barhoumi Z, et al. Effects of two composts and two grasses on microbial biomass and biological activity in a salt-affected soil. Ecol Eng. 2013;60:363-369. DOI: 10.1016/j.ecoleng.2013.09.002. http://linkinghub.elsevier.com/retrieve/pii/S0925857413003479.

[29] Mylavarapu RS, Zinati GM. Improvement of soil properties using compost for optimum parsley production in sandy soils. Scientia Horticult. 2009;120(3):426-430. DOI: 10.1016/j.scienta.2008.11.038. http://linkinghub.elsevier.com/retrieve/pii/S0304423808005049.

[30] Hidayt H, Keijsers ERP, Prijanto U, Dam JEG, Heeres HJ. Preparation and properties of binderless boards from Jatropha curcas L. seed cake. Indust Crops Products. 2014;52:245-254. DOI: 10.1016/j.indcrop.2013.10.024. http://linkinghub.elsevier.com/retrieve/pii/S0926669013005761.

[31] Srinophakun P, Titapiwatanakun B, Sooksathan I, Punsuvon V. Prospect of deoiled Jatropha curcas seedcake as fertiliyer for vegetables crops - A case study. J Agricult Sci. 2012;4(3):211-226. DOI: 10.5539/jas.v4n3p211. http://www.ccsenet.org/journal/index.php/jas/article/view/11792. 